ARTIKEL PENELITIAN

\title{
Optimisme sebagai Moderator pada Pengaruh Job Insecurity terhadap Happiness at Work Karyawan Saat Pandemi
}

\author{
NOVI TRI MEGA SELVIANA \& DEWI SYARIFAH* \\ Fakultas Psikologi Universitas Airlangga
}

\begin{abstract}
ABSTRAK
Penelitian ini bertujuan untuk menguji ada tidaknya pengaruh job insecurity terhadap happiness at work dan adakah peran optimisme sebagai moderator pada pengaruh job insecurity terhadap happiness at work karyawan saat pandemi covid-19. Penelitian ini adalah penelitian kuantitatif dengan metode survei yang diikuti oleh 102 karyawan hospitality industry. Alat ukur yang digunakan antara lain happiness at work measurement scale (11 aitem), job insecurity scale (4 aitem), dan lot-r (6 aitem). Adapun hasil penelitian ini menyatakan bahwa job insecurity berpengaruh signifikan terhadap happiness at work serta optimisme tidak mampu memoderasi pengaruh job insecurity kerja terhadap happiness at work.
\end{abstract}

Kata kunci: happiness at work, job insecurity, optimisme

\begin{abstract}
This study aims to examine whether there is an effect of job insecurity on happiness at work and optimism as a moderator on the effect of job insecurity on happiness at work during the Covid-19 pandemic. This is a quantitative research with a survey method followed by 102 employees of hospitality industry. The measuring instruments include happiness at work measurement scale (11 items), job insecurity scale (4 items), and lot-r ( 6 items). The results state that job insecurity has a significant effect on happiness at work and optimism not able to moderate the effect of job insecurity on happiness at work.
\end{abstract}

Keywords: happiness at work, job insecurity, optimism

Buletin Penelitian Psikologi dan Kesehatan Mental (BRPKM), 2021, Vol. 1(1), 870-882

*Alamat korespondensi: Fakultas Psikologi Universitas Airlangga, Kampus B Universitas Airlangga Jalan

Airlangga 4-6 Surabaya 60286. Surel: dewi.syarifah@psikologi.unair.ac.id

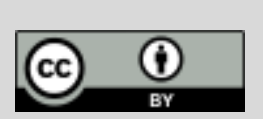

Naskah ini merupakan naskah dengan akses terbuka dibawah ketentuan the Creative Common Attribution License (CC-BY-4.0) (http://creativecommons.org/licenses/by/4.0), sehingga penggunaan, distribusi, reproduksi dalam media apapun atas artikel ini tidak dibatasi, selama sumber aslinya disitir dengan baik. 


\section{P E N D A H U L U A N}

Pada akhir tahun 2019, WHO menginformasikan bahwa telah terjadi wabah di Kota Wuhan yang kemudian dikenal dengan sebutan Coronavirus atau COVID-19. Virus ini telah berkembang cepat menjadi pandemi yang melanda berbagai bagian negara. Hingga sekitar awal tahun 2020, COVID-19 ini berhasil menginfeksi Indonesia. Dilansir dari situs WHO per tanggal 26 Januari 2021, jumlah kasus COVID-19 di Indonesia tercatat sebanyak 989.262 orang positif terpapar dan 27.835 orang meninggal. Berbagai upaya diterapkan pemerintah agar dapat memutus rantai penyebaran COVID19. Tingkat kesadaran dan kepatuhan masyarakat akan segala kebijakan yang dikeluarkan pemerintah, sayangnya tidak dapat bersaing untuk membendung penularan COVID-19 yang semakin meningkat. Dampaknya adalah terjadi perubahan drastis pada banyak bidang dalam kehidupan masyarakat, salah satunya ialah aspek psikologis (Mutawalli, dkk., 2020). Adanya anjuran pemerintah untuk tetap berada di rumah saja serta kebijakan yang membatasi aktivitas yang biasa dilakukan, sedikit banyak telah menimbulkan jarak secara fisik maupun emosional dalam masyarakat. Hasil survei PDSKJI 2020 menunjukkan, sebanyak 63\% orang di masa pandemi mengalami cemas berlebihan akan sesuatu buruk dan 66\% lainnya mengalami depresi akibat pandemi COVID-19 (Winurini, 2020).

Kesejahteraan psikologis, serta ketidaksiapan dan kurangnya pengetahuan masyarakat dalam menghadapi situasi pandemi ini dapat memicu timbulnya stres atau kecemasan yang berlebihan bagi masyarakat (Mutawalli, dkk., 2020). Di China sendiri pandemi ini sangat berdampak pada kondisi psikologis orang tua dengan gejala depresi yang meningkat pada diri mereka dikarenakan kebijakan terkait COVID-19 (Yang, dkk., 2020). Satu dari dua penduduk usia produktif mengalami stres dan depresi, mayoritas penyebabnya karena dampak dari pandemi COVID-19 ini (International Labour Organization, 2020).

Kondisi psikologis yang terdampak saat pandemi ini dapat mempengaruhi kesejahteraan seseorang, yang dalam penelitian ini fokusnya pada kesejahteraan psikologis pekerja. Kesejahteraan psikologis menjadi hal penting yang perlu diperhatikan perusahaan dan pekerja itu sendiri. Kesejahteraan psikologis pekerja dipengaruhi oleh kesejahteraan dari tempat kerjanya. Kesejahteraan dari tempat kerja ini dapat tercipta bila ada kebahagiaan di tempat kerja. Menjadi bahagia merupakan hal yang sangat penting dan kebahagiaan telah ditemukan sebagai tujuan yang sangat berharga di sebagian besar masyarakat (Diener, 2000). Veenhoven (2003) mendefinisikan kebahagiaan sebagai derajat sebutan terhadap kualitas hidup yang menyenangkan dari seseorang (Veenhoven, 2003). Merasa bahagia adalah dasar pengalaman manusia, dan kebanyakan orang merasa bahagia di sebagian besar waktunya (Diener \& Diener, 1996). Sedangkan seseorang akan lebih banyak menghabiskan banyak waktunya ketika dewasa dengan bekerja dibandingkan menghabiskan waktunya dengan keluarga, teman, dan hobinya (Duari \& Sia, 2013).

Kebahagiaan di tempat kerja (happiness at work) menurut Pryce-Jones (2010) merupakan pola pikir seseorang untuk memaksimalkan kinerja dan mencapai potensinya. Happiness at work menjadi sangat penting bagi karyawan karena karyawan yang bahagia di tempat kerja memiliki perasaan positif pada kepuasan hidup, produktif dalam bekerja, dan mengurangi turnover sehingga dapat membangun sumber daya manusia yang berkualitas (Ningsih, 2013). Sumber daya manusia yang dalam hal ini ialah karyawan yang mana merupakan aset utama perusahaan yang memiliki peran aktif dalam setiap aktivitas perusahaan, baik sebagai perencana, pelaku dan penentu tercapainya tujuan perusahaan. Oleh karena itu, kualitas kinerja karyawan sangat diperlukan agar dapat meningkatkan profit perusahaan dan pada akhirnya dapat mengembangkan perusahaan menjadi lebih baik. 
Hal tersebut semakin diperkuat oleh Gupta (2012) bahwa kebahagiaan pekerja dapat menghasilkan produktivitas yang lebih tinggi, profitabilitas, kesuksesan, kepuasan, komitmen, dan kerja tim dalam suatu organisasi atau pekerjaan (Gupta, 2012). Secara signifikan ini saling berkaitan antara kebahagiaan karyawan dan kinerja organisasi, komitmen dan kelangsungan hidup organisasi (Grant, dkk., 2007). Oleh karenanya, pekerja yang bahagia memiliki sedikit kemungkinan untuk mengalami stres, kelelahan, dan penarikan diri namun memiliki skor produktivitas yang tinggi (Lyubomirsky, dkk., 2005).

Berdasarkan pemaparan hasil survei Jobstreet, tingkat kebahagiaan pekerja saat pandemi COVID-19 menurun signifikan sebanyak 41\% dan sebaliknya pada ketidakbahagiaan naik 29\% (CNN Indonesia, 2020a). Hal senada dengan penelitian Li, dkk. (2020) menunjukkan bahwa terjadi peningkatan emosi negatif (cemas, stres) dan penilaian risiko, sementara emosi positif (kebahagiaan, kepuasan hidup) mengalami penurunan. Sementara di Indonesia, hasil survei Iskandarsyah \& Yudiana (2020) menunjukkan 78\% partisipan cemas dengan penyebaran COVID-19 dan 23\% merasa tidak bahagia atau dalam kondisi tertekan. Terdapat beberapa hal yang dapat berkontribusi menciptakan kebahagiaan di tempat kerja seperti; dapat meraih goals yang dimiliki, dapat mengangkat masalah yang dianggap penting, memiliki objektivitas terhadap pekerjaan, merasa didengarkan dan dihargai, menerima feedback positif dari pekerjaan, dan merasa aman saat bekerja (Pryce-Jones, 2010).

Perasaan aman merupakan rasa aman dari berbagai bahaya yang dapat mengancam keadaan diri karyawan. Wursanto (2009), menjabarkan perasaan aman tersebut terdiri dari rasa aman dari bahaya yang mungkin timbul pada saat menjalankan tugasnya, rasa aman dari pemutusan hubungan kerja yang dapat mengancam penghidupan diri dan keluarganya, dan rasa aman dari bentuk intimidasi ataupun tuduhan dari adanya kecurigaan antar karyawan (Wursanto, 2009). Dooley (1987 dalam Pradiansyah, 1999) di Amerika Serikat menyatakan persepsi kondisi kerja yang tidak aman sangat menentukan kondisi psikologis seseorang. Perasaan tidak aman inilah yang melahirkan depresi, stres, kecemasan, perasaan tidak berharga, putus asa, dan berkurangnya rasa percaya diri. Kondisi ini kemudian disebut dengan istilah ketidakamanan kerja (job insecurity).

Sebagai bagian dari lingkungan kerja non fisik, ketidakamanan kerja menjadi faktor penting untuk menentukan apakah karyawan merasakan kebahagiaan dalam bekerja. Berdasarkan pendekatan teoritis (teori stres, teori conservation of research, dan teori kontrak psikologis) hubungan kebahagiaan di tempat kerja dan ketidakamanan kerja bersifat negatif. Hasil penelitian yang dilakukan baru-baru ini juga menunjukkan interaksi negatif antara kedua konstruk tersebut. Temuan penelitian itu mendukung pandangan bahwa ketidakamanan kerja adalah penyebab stres kerja yang mengganggu kebahagiaan karyawan (Stankevičiūtè, dkk., 2021).

Kualitas hidup yang rendah selama pandemi telah mempengaruhi tingkat kebahagiaan (CNN Indonesia, 2020). Adanya pandemi COVID-19 seperti yang telah dijelaskan sebelumnya, bila terus berlanjut dengan ketidakpastian kapan akan berakhir, maka hal ini menyebabkan para pekerja mengalami kecemasan yang mengarah pada ketidakamanan kerja (job insecurity). Job insecurity menurut Saylor (2004) dapat diartikan sebagai perasaan khawatir, gelisah, stres, dan merasa tidak pasti yang berkaitan dengan pekerjaan saat itu dan kedepannya (Saylor, 2004). Job insecurity yang dirasakan bergantung pada persepsi individual (Rosenblattt \& Ruvio, 1996). Persepsi tersebut dapat bermacam-macam, seperti persepsi sebagai fungsi keadaan tujuan dan sebagai fungsi atribut personal. Menurut De Witte (2005) job insecurity dapat menimbulkan stres, menurunkan kepuasan kerja, motivasi kerja dan rasa percaya terhadap organisasi. Penelitian dari College of Health di Ball State University menambahkan bahwa persepsi job insecurity sangat menegangkan sehingga karyawan seringkali menderita berbagai masalah fisik dan psikologis, termasuk penyakit jantung, 
kurang tidur dan tekanan psikologis. Selain hal tersebut, persepsi job insecurity diiringi oleh beberapa kondisi negatif seperti dapat menurunkan komitmen, merasakan kecemasan, depresi dan menurunnya kepuasan kerja (Emanuel, dkk., 2018). Dampak lain job insecurity dari Ashford, dkk. (1989) adalah menambah biaya organisasi. Selain itu adanya penurunan komitmen karyawan, kepercayaan pada suatu organisasi, dan kepuasan kerja dan dengan meningkatnya niat untuk berhenti atau keluar dari pekerjaannya. Dampak-dampak negatif persepsi job insecurity di atas cenderung menurunkan tujuan organisasi dan membuat karyawan berkontribusi rendah terhadap perusahaannya (De Witte, 2005).

Faktor lain yang mempengaruhi happiness at work adalah sikap optimis. Terdapat tiga faktor internal yang berkontribusi terhadap kebahagiaan, yaitu kepuasan terhadap masa lalu, optimisme terhadap masa depan, dan kebahagiaan pada masa sekarang (Seligman, 2002). Seligman, dkk., (1995) mengatakan bahwa dalam bekerja, pola pikir yang digunakan seorang individu akan mempengaruhi seluruh bidang kehidupannya, termasuk pola pikir yang positif. Menurut Segestrom (1998 dalam Nandini, 2016), optimisme adalah cara berpikir yang positif dan realistis dalam memandang suatu masalah. Kehadiran optimisme dalam diri seseorang diyakini akan mengantarkan individu pada kebahagiaan.

Hal tersebut didukung oleh penelitian yang dilakukan oleh Pflug (2009) terhadap 55 responden di Afrika selatan yang memberikan hasil bahwa optimisme mempunyai korelasi yang sangat signifikan terhadap kebahagiaan. Juga penelitian yang dilakukan oleh Elena (2014) terhadap 174 responden yang memberikan hasil bahwa optimisme memiliki korelasi yang sangat signifikan terhadap kebahagiaan walaupun ada faktor lain yang mempengaruhi. Kemudian, penelitian Zheng, dkk. (2014) tentang job insecurity dan job satisfaction mengidentifikasi optimisme sebagai faktor moderasi yang dapat mengurangi dampak negatif dari ketidakamanan kerja terhadap kepuasan kerja.

Hasil penelitian Harter, Schmidt, dan Keyes menegaskan bahwa optimisme memiliki pengaruh yang signifikan untuk kesejahteraan pekerja (Malik, 2013). Seorang karyawan dengan optimisme yang tinggi akan memiliki produktivitas yang baik dalam pekerjaan, dan akan merasa lebih bahagia. Jika karyawan merasa bahagia, maka performa karyawan menjadi lebih baik sehingga aktivitas di dalam perusahaan akan stabil dan hal itu kemudian memberi keuntungan tersendiri bagi perusahaan. (Revesencio, 2015) mengatakan bahwa karyawan yang bahagia, produktivitasnya meningkat sebanyak $12 \%$. Perusahaan tentu tidak akan terkena dampak negatif akibat menurunnya kinerja karyawan, bahkan karyawan akan terpacu untuk lebih berkontribusi secara penuh untuk meningkatkan kualitas dan keberhasilan sebuah perusahaan. Berdasarkan uraian diatas, peneliti ingin mengkaji dan meneliti tentang apakah terdapat pengaruh job insecurity terhadap kebahagiaan karyawan swasta di tempat kerja selama pandemi dengan optimisme sebagai moderatornya.

\section{E T O D E}

\section{Desain Penelitian}

Penelitian ini menggunakan tipe penelitian kuantitatif, yaitu penelitian dengan menekankan analisisnya menggunakan angka atau data-data numerik yang akan diolah dengan metode statistik (Saifudin, 2001). Menurut Neuman (2007) pengambilan data pada penelitian kuantitatif disini mempunyai 3 metode, yaitu survei, eksperimen, dan non reactive research (Neuman, 2007). Metode yang digunakan dalam penelitian ini adalah metode survei. Survei dalam penelitian ini bertujuan untuk menjaring partisipan yang memiliki karakteristik sesuai yang telah ditentukan peneliti untuk 
meminimalisir kesesatan penelitian yang mungkin muncul. Variabel bebas atau independent variable yang digunakan dalam penelitian ini adalah job insecurity. Sedangkan, variabel terikat atau dependent variable yang digunakan dalam penelitian ini adalah happiness at work dengan optimisme sebagai variabel moderator.

Penelitian ini menggunakan purposive sampling sebagai salah satu bentuk dari non probability sampling, yakni teknik pemilihan sampel dengan menggunakan beberapa pertimbangan tertentu seperti adanya ciri-ciri yang sama pada populasi, ataupun memilih beberapa sampel tertentu yang dinilai akan sesuai dengan masalah penelitian (Margono, 2004). Partisipan yang dipilih oleh peneliti dalam penelitian ini memiliki karakteristik sebagai berikut: laki-laki atau perempuan, berusia 15-65 tahun, dan merupakan karyawan perusahaan di bidang Hospitality Industry (Restaurant/Cafe, penginapan, tempat rekreasi/hiburan, serta jasa transportasi dan perjalanan).

Teknik pengumpulan data yang digunakan oleh peneliti pada penelitian ini adalah data primer. Data primer adalah jenis data yang didapatkan secara langsung dari partisipan melalui alat ukur yang disiapkan oleh peneliti, sedangkan data sekunder merupakan data yang didapatkan dari pihak lain selain partisipan (Neuman, 2014). Metode pengumpulan data dalam penelitian ini menggunakan survei online yang berisi kueisioner. Kuesioner adalah alat yang digunakan untuk mengumpulkan data yang berisikan beberapa pertanyaan yang harus dijawab oleh partisipan sesuai dengan kondisi, karakteristik, perilaku yang dirasakan. Pertanyaan tersebut berisi mengenai konsep dan atribut psikologis atau variabel penelitian (Neuman, 2014).

\section{Partisipan}

Karakteristik partisipan yang dipilih oleh peneliti dalam penelitian ini adalah sebagai berikut: lakilaki atau perempuan, berusia 15-65 tahun, dan merupakan karyawan perusahaan di bidang hospitality industry (restaurant/cafe, penginapan, tempat rekreasi/hiburan, dan jasa transportasi dan perjalanan). Pemilihan partisipan tersebut didasarkan oleh realitas bahwa dampak pandemi COVID-19 telah menghentikan roda bisnis beberapa sektor industri. Salah satu sektor industri yang paling terpapar dampak pandemi adalah hospitality industry (Liputan 6, 2014). Karyawan hospitality dilaporkan telah banyak mengalami pemutusan kontrak kerja, dirumahkan, pengurangan gaji, dan kebijakan lainnya yang dapat mengancam pekerjaan mereka.

\section{Pengukuran}

Pada penelitian ini terdapat tiga macam skala, yaitu job insecurity scale (JIS), Happiness at Work Measurement Scale, dan Revised Life Orientation Test (LOT-R).JIS dikembangkan oleh De Witte (2000) yang berjumlah 4 aitem dengan rentang skalanya dari 1 (Sangat Tidak Setuju), 2 (Tidak Setuju), 3 (Setuju), dan 4 (Sangat Setuju) (Ramdhan, 2020). Koefisien reliabilitas JIS ini menghasilkan 0.95 Alpha Cronbach. Sedangkan happiness at work measurement scale disusun oleh Garcia, dkk. (2019) yang berjumlah 11 aitem berbentuk skala Likert 6 poin dari sangat tidak setuju sampai sangat setuju. Seluruh aitem disusun berdasarkan pada 2 dimensi, yaitu job environment (lingkungan pekerjaan) dan workers factor (faktor pekerja) (Garcia, dkk., 2019). Alat ukur ini memiliki Cronbach Alpha 0.88 dengan reliabilitas tiap dimensi bernilai sebesar 0.91 dan 0.72 . Kemudian yang terakhir adalah Revised Life Orientation Test (LOT-R) (Scheier, dkk., 1994) yang berjumlah 6 aitem dengan nilai $a=0$,78. $L O T$ - $R$ disusun dengan model skala Likert yang memiliki 5 skala interval mulai dari $1=$ Sangat Tidak Setuju (STS), 2=Tidak Setuju (TS), 3=Setuju (S), dan 4=Sangat Setuju (SS).

\section{Analisis Data}

Setelah didapatkan data dari pengisian kueisioner oleh partisipan penelitian, data akan dianalisis untuk menguji hipotesis yang sudah dipaparkan sebelumnya pada penelitian ini, Analisis data yang 
dibutuhkan dalam pengujian hipotesis pada penelitian ini menggunakan linear regression analysis dan moderated regression analysis (MRA) dengan bantuan aplikasi IBM SPSS Statistics 22 for Windows. Sebelum dilakukan pengujian hipotesis, diperlukan analisis deskriptif untuk mengetahui karakteristik data yang dimiliki, kemudian dilakukan uji asumsi untuk syarat melakukan analisis regresi diantaranya ada uji normalitas data, uji linearitas, uji heteroskedastisitas, uji multikolinearitas, dan uji korelasi. Setelah dilakukan tahapan uji tersebut dan dinyatakan memenuhi maka bisa dilakukan uji hipotesis analisis regresi linear sederhana dan MRA.

\section{HASIL PENELITIAN}

\section{Uji Deskriptif}

Hasil analisis deskriptif menunjukkan bahwa partisipan yang memiliki happiness at work kategori rendah sebanyak 12 orang (11,7\%). Partisipan dengan happiness at work kategori sedang sebanyak 69 orang $(67,6 \%)$ dan kategori tinggi sebanyak 21 orang $(20,5 \%)$. Sedangkan partisipan yang mengalami job insecurity kategori rendah sebanyak 19 orang $(18,6 \%)$, kategori sedang 24 orang $(23,5 \%)$, dan 59 orang $(57,8 \%)$ termasuk dalam kategori tinggi. Partisipan yang merasakan optimisme tinggi dalam penelitian ini sebanyak 27 orang (26,4\%), kategori sedang sebanyak 69 orang $(67,6 \%)$, dan kategori rendah sebanyak 6 orang $(5,8 \%)$.

\section{Uji Regresi Linear Sederhana}

Hasil analisis regresi linear sederhana antara job insecurity terhadap happiness at work menunjukkan bahwa job insecurity berpengaruh terhadap happiness at work karyawan sebesar 7,9\% ( $p<0,004$; $R^{2}=0,079 ; t=-2,919$ ).

\section{Uji Interaksi}

Moderated Regression Analysis (MRA) atau uji interaksi dilakukan untuk mengetahui pengaruh variabel optimisme sebagai moderator job insecurity terhadap happiness at work. Berdasarkan hasil analisis $M R A$, diperoleh 9,9\% ( $\left.p>0,68 ; R^{2}=0,099\right)$. Job insecurity secara signifikan berpengaruh dengan sifat negatif terhadap happiness at work pada karyawan saat pandemi $(B=0,312 ; T=0,414 ; p>0,68)$. Artinya, variabel optimisme tidak memiliki pengaruh juga tidak dapat memoderasi secara signifikan terhadap variabel Y.

\section{I S K U S I}

$\mathrm{H}_{1}$ dalam penelitian ini adalah adanya pengaruh job insecurity terhadap happiness at work karyawan. Hasil penelitian menyatakan bahwa $\mathrm{H}_{1}$ diterima berdasarkan hasil uji regresi linear sederhana variabel X terhadap variabel Y yang signifikan. Menurut Alcover (2020 dalam Febiola, 2020), job insecurity memiliki pengaruh negatif terhadap kesehatan psikologis seseorang selama masa pandemi. Kesehatan psikologis yang menurun akibat peningkatan perasaan job insecurity akan mengakibatkan tingkat kesejahteraan psikologis seseorang menurun (Rocha, dkk., 2006). Kesejahteraan psikologis yang dimaksud disini adalah kesejahteraan psikologis karyawan yang mana salah satunya dipengaruhi oleh kesejahteraan atau kebahagiaan dari tempat kerjanya.Hubungan happiness at work dan job insecurity bersifat negatif (Stankevičiūtè, dkk., 2021). Arah korelasi job insecurity terhadap happiness at work pada penelitian ini bernilai negatif sehingga apabila terjadi peningkatan nilai pada job insecurity, maka tingkat happiness at work akan menurun 
dan begitu juga sebaliknya. Dengan kata lain, job insecurity yang timbul dari rasa takut karyawan di masa pandemi ini dapat menurunkan tingkat happiness at work karyawan.

H2 dalam penelitian ini adalah terdapat peran moderasi optimisme pada pengaruh job insecurity terhadap happiness at work karyawan. $\mathrm{H}_{2}$ ditolak berdasarkan hasil analisis MRA dengan uji $T$ yang memperoleh hasil yang tidak signifikan. Tidak adanya pengaruh optimisme sebagai moderator pada penelitian ini dapat dijelaskan melalui uji normalitas data variabel $\mathrm{Z}$ yang tidak signifikan atau data variabel optimisme tidak berdistribusi normal. Dapat diasumsikan berdasarkan hasil yang tidak normal ini, data menjadi kurang sensitif dalam membaca hasil penelitian yang bisa saja memiliki efek moderasi. Data yang tidak tersebar normal dapat meningkatkan bias pada penelitian (Akseleran, 2010).

Selain itu, Carver \& Scheier (2002) menambahkan bahwa optimisme dapat mempengaruhi bila ada pengaturan diri yang baik. Pengaturan diri ini diatur berdasarkan locus of control yang ada pada seseorang (Rotter, 1966). Seseorang yang mempunyai locus of control internal berkeyakinan bahwa mereka dapat mengendalikan apa yang terjadi pada mereka. Sebaliknya, seseorang yang mempunyai locus of control eksternal berkeyakinan bahwa kesempatan, nasib, dan keberuntungan menentukan apa yang terjadi pada mereka (Trevino, 1986). Hal ini sejalan dengan hasil penelitian Lin \& Ding (2003) yang menunjukkan bahwa locus of control dan job insecurity dapat memoderasi kendali perilaku persepsian dengan intensi perilaku.

Tingkat kemampuan kontrol (controllability) atas suatu situasi tersebut dapat mempengaruhi keberhasilan strategi koping atau regulasi emosi seseorang dalam mengatasi situasi (Heth \& Somer, 2002). Penilaian kognitif termasuk pada tipe koping dengan fokus emosional (emotion-focused coping) sehingga hal yang dapat dikontrol hanyalah emosi. Penilaian kognitif dinilai efektif apabila diaplikasikan seseorang dalam mengatasi situasi yang tidak terkontrol (uncontrollable stressor), namun menjadi maladaptif ketika stresor dapat dikontrol (Troy, dkk., 2013). Saat seseorang mempersepsikan job insecurity pada pandemi ini sebagai stresor yang dapat dikendalikan, maka dapat disimpulkan bahwa emotion-focused coping seperti dengan adanya optimisme menjadi tidak terlalu efektif untuk diterapkan. Hal ini didukung oleh pernyataan bahwa cognitive reappraisal (CRA) menjadi kurang efektif apabila digunakan pada stresor terkontrol (Troy, dkk., 2013). Akan lebih efektif apabila diatasi dengan problem-focused coping, seperti mulai melakukan perubahan dengan meningkatkan skill, mengasah kreativitas, giat bekerja dan tidak prokrastinasi.

Determinasi diri tinggi pada seseorang juga dapat memprediksi bagaimana orang tersebut dapat beradaptasi dengan perubahan (Amiot, dkk., 2008). Seseorang dengan determinasi diri tinggi akan lebih mampu mengelola perubahan dengan menggunakan strategi koping yang berorientasi tugas (perencanaan dan strategi koping aktif) (Amiot, dkk., 2010). Strategi koping perencanaan bertujuan untuk mengubah situasi di masa depan dan strategi koping aktif merupakan strategi yang bertujuan pada manajemen (Skinner, dkk., 2003). Partisipan dengan determinasi diri tinggi cenderung untuk menerapkan strategi koping berorientasi tugas (baik koping aktif maupun perencanaan) daripada partisipan dengan determinasi diri rendah (Parker, dkk., 2013). Meskipun determinasi diri yang mempengaruhi jenis koping individu ini hanya tidak dapat dikontrol dalam penelitian namun tetap saja dapat mempengaruhi.

Ditolaknya efek moderasi variabel optimisme pada pengaruh job insecurity terhadap happiness at work juga dapat dijelaskan melalui kategori usia. Karakteristik partisipan penelitian ini didominasi oleh karyawan usia 16-25 tahun. Kepuasan hidup meningkat perlahan seiring dengan usia dan perasaan tidak menyenangkan cenderung stabil. Hal ini diduga karena regulasi emosi pada individu 
kelompok usia dewasa madya dan akhir dapat meningkatkan kesejahteraan psikologis daripada karyawan usia dewasa awal. Pada umumnya, individu kelompok usia dewasa akhir cenderung menggunakan strategi regulasi emosi lebih adaptif (penilaian ulang, pemecahan masalah, dan deep acting) daripada strategi kurang adaptif (penekanan dan surface acting) sehingga dapat meningkatkan kesejahteraan psikologisnya yang didalamnya meliputi happiness at work karyawan (Seligman, 2002; Muza, 2021). Oleh karena itu, partisipan yang didominasi oleh kelompok usia dewasa awal pada penelitian ini dapat menghasilkan hasil moderasi yang tidak signifikan.

Tidak ada individu yang kebal terhadap perasaan negatif terkait dengan job insecurity, meskipun seorang karyawan memiliki optimisme yang tinggi, mereka bukanlah manusia super. Semua karyawan mengalami pasang surut emosi dan tendensi individu untuk menjadi optimis memerlukan suasana hati atau sikap yang terkait dengan harapan tentang masa depan atau material yang berbeda (Tiger, 1979; Weiss \& Cropanzano, 1996; Jordan, dkk., 2002). Terbentuknya pola pikir optimis tergantung juga pada cara pandang seseorang pada perasaan dirinya bernilai atau tidak yang biasanya tumbuh dari pengakuan dan lingkungan sehingga orang yang optimis percaya bahwa lingkungan turut memberi andil atas peristiwa yang dialaminya (Seligman, 1991).

Menurunnya interaksi dengan lingkungan akibat kebijakan social distancing pada masa pandemi ini, sedikit banyak telah mempengaruhi adanya dukungan sosial dalam diri seseorang yang dapat membuat individu kurang optimis karena merasa bantuan tidak mudah didapat bila dibutuhkan (Seligman, 2008). Dukungan sosial yang baik dari orang-orang disekitar dapat membantu dan berpengaruh pada tingkat kesejahteraan psikologisnya (Febiola, 2020). Akan tetapi apabila kondisi ketenagakerjaan saat ini tidak menentu dan keadaan ekonomi yang semakin terpuruk terus berlanjut tanpa ada perubahan meskipun seseorang telah optimis, maka keyakinan diri pada seseorang menjadi tidak cukup kuat dan menghambat seseorang mencapai kebahagiaan (Purmadani, 2014). Ini menjadikan optimisme tidak dapat menghalau seseorang untuk merasakan kecemasan yang akan mempengaruhi kebahagiaan kerjanya.

Ahli teori fungsional sosial telah lama berpendapat bahwa bahkan emosi yang tidak menyenangkan seperti pesimisme memiliki peran berharga untuk kehidupan sosial dan pekerjaan (Keltner \& Haidt, 1999). Bila emosi positif adalah penghargaan, maka emosi negatif adalah peringatan dan hukuman (Larsen \& Ketelaar, 1989). Suasana hati positif sangat penting untuk fungsi sehari-hari dan kerja sama, namun suasana hati negatif sangat penting untuk menanggapi kelangsungan hidup (Zajonc, 1998). Taylor (1991) berpendapat bahwa proses mobilisasi awal dari emosi negatif bertujuan menggembleng sumber daya internal untuk mengarahkan perhatian dan perilaku ke arah penyelesaian masalah yang dihadapi, dan seiring waktu berusaha untuk memperbaiki dampak peristiwa negatif. Hal ini konsisten dengan gagasan bahwa emosi negatif adalah respons berorientasi adaptif. Stres akibat kecemasan akan kondisi kerja yang tidak menentu menjadi sinyal peringatan melakukan perubahan bagi sebagian individu, tetapi sebagian individu lain justru semakin terpuruk dan tidak menggunakan peringatan itu secara produktif. Adanya perasaan negatif dalam job insecurity mungkin saja dapat bersifat adaptif karena memotivasi seseorang untuk mencari solusi dan menyelesaikan permasalahannya. Dengan demikian, banyak variasi dalam keadaan afektif bersifat intrapersonal (Weiss, dkk., 1999).

Berdasarkan penjelasan tersebut, dapat disimpulkan bahwa kemungkinan mengapa optimisme tidak memoderasi pengaruh job insecurity terhadap happiness at work adalah karena pada beberapa karyawan mungkin lebih baik dalam mengendalikan situasi dengan memanfaatkan pesimisme daripada optimismenya. 


\section{S I M P U L A N}

Berdasarkan hasil penelitian yang telah dilakukan dan pengujian hipotesis, maka dapat ditarik kesimpulan bahwa job insecurity berpengaruh signifikan terhadap happiness at work karyawan saat pandemi COVID-19. Melalui hasil penelitian ini juga diketahui bahwa optimisme tidak memiliki peran moderasi antara job insecurity terhadap happiness at work.

\section{U C A P A N T E R I M A KAS I H}

Penulis ingin mengucapkan terima kasih sebesar-besarnya terhadap pihak-pihak membantu dalam penulisan naskah ini. Terima kasih kepada Dewi Syarifah, M.Psi., Psikolog, selaku dosen pembimbing penulis, kepada seluruh dosen pengajar dan staf di Fakultas Psikologi Universitas Airlangga, partisipan penelitian ini dan seluruh pihak yang tidak dapat disebutkan satu-persatu.

\section{DEKLARASI POTENSI TERJADINYA KONFLIK KEPENTINGAN}

Novi Tri Mega Selviana dan Dewi Syarifah tidak bekerja, menjadi konsultan, memiliki saham, atau menerima dana dari perusahaan atau organisasi manapun yang mungkin akan mengambil untung dari diterbitkannya naskah ini.

\section{PUSTAKA ACUAN}

Akseleran. (2010). Lebih Dalam Mengenal Distribusi Normal dalam Statistik. https://www.akseleran.co.id/blog/distribusi-normal/

Amiot, C. E.; Blanchard, C. M.; Gaudreau, P. (2008). The self in change: A longitudinal investigation of coping and self-determination processes. Self and Identity, 204-224.

Amiot, C. E.; Gaudreau, P. (2010). Coping and self-determination in sport: Underlying mechanisms and empirical evidence. In A. Nicholls (Ed.), Coping in sport: Concepts, theories, and related constructs.

Ashford, S. J; Lee, C; Bobko, P. (1989). Content, Cause, and Consequences of Job Insecurity: A TheoryBased Measure and Substantive Test. Academy of Management Journal, 32(4), 803-829.

Carver, C. S; Scheier, M. F. (2002). Optimism. In Handbook of Positif Psychology (pp. 231-243). Oxford University Press.

CNN Indonesia. (2020a). Kebahagiaan Pekerja Indonesia Menurun Drastis Selama Pandemi. https://www.cnnindonesia.com/gaya-hidup/20201007172324-284-555610/kebahagiaanpekerja-indonesia-menurun-drastis-selama-pandemi

De Witte, H. (2005). Job insecurity: Review of the international literature on definitions, prevalence, antecedents and consequences. SA Journal of Industrial Psychology, 31(4).

Diener, E; Diener, C. (1996). Most people are happy. Psychological Science, 181-185.

Diener, E. (2000). Subjective Well-Being. American Psychologist, 5, 34-43. 
Duari, P; Sia, S. . (2013). Importance of Happiness at Workplace. Indian Journal of Positive Psychology, $4(3), 453-456$.

Elena. (2014). Psychological predictors and mediators of subjective well-being in a sam-ple pf romanian teachers. Revista de Cercetare Si Interventie Soci-Ala, 37-52.

Emanuel, F; Molino, M; Presti, A. Lo; Spagnoli, P; Ghislieri, C. (2018). A crossover study from a gender perspective: The relationship between job insecurity, job satisfaction, and partners' family life satisfaction. Frontiers in Psychology, 1-10.

Febiola, M. (2020). Regulasi Emosi Sebagai Moderator Pada Pengaruh Ketidakamanan Kerja Terhadap Kesejahteraan Psikologis Selama Pandemi Covid-19. In Ir - Perpustakaan Universitas Airlangga.

Garcia, Carolina Ramirez; Alvarez De Perea, Juan Garcia; Del Junco, J. G. (2019). Happiness at work: Measurement scale validation. Journal of Business Management, 59(5), 327-340.

Grant, A.M; Christianson, M.K.; Price, R. . (2007). Happiness, Health, or Relationships? Managerial Practices and Employee Well-Being Tradeoffs. Academy Managerial Perspective, 51-63.

Gupta. (2012). Importance of Being Happy at Work. Journal Issue, 1(1), 2319-5479.

Heth, J. T., \& Somer, E. (2002). Characterizing stress toler- ance: "Controllability awareness" and its relationship to perceived stress and reported health. Personality and Individual Differences, 883-895.

International Labour Organization. (2020). ILO survey on COVID-19's impact on youth employment. https://www.ilo.org/global/about-the-ilo/multimedia/video/institutionalvideos/WCMS_753073/lang--en/index.htm

Iskandarsyah, A; Yudiana, W. (2020). Informasi Covid-19, Perilaku Sehat Dan Kondisi Psikologis di Indonesia. Laporan Survei.

Jordan, P. J., Ashkanasy, N. M., \& Hartel, C. E. J. (2002). Emotional Intelligence as a Moderator of Emotional and Behavioral Reactions to Job Insecurity. In The Academy of Management Review (Vol. 27, Issue 3). https://doi.org/10.2307/4134384

Keltner, D; Haidt, J. (1999). Social functions of emotions at four levels of analysis. Cognition and Emotion, 505-521.

Larsen, R. J; Ketelaar, T. (1989). Extraversion, neuroticism, and susceptibility to positive and negative mood induction procedures. Personality and Individual Differences, 1221-1228.

Li, S; Wang, Y; Xue, J; Zhao, N; Zhu, T. (2020). The Impact of COVID-19 Epidemic Declaration on Psychological Consequences: A Study on Active Weibo Users. International Journal of Environment Research and Public Health, 3(2).

Lin, Chieh-Peng; Ding, C. G. (2003). Modeling Information Ethics: The Joint Moderating Role of Locus 
of Control and Job Insecurity. Journal of Business Ethics, 335-346.

Liputan 6. (2014). 5 Keuntungan Sikap Optimis untuk Karir Anda. https://www.liputan6.com/bisnis/read/820357/5-keuntungan-sikap-optimis-untuk-kariranda

Lyubomirsky, S; King, L; Diener, E. (2005). The Benefits of Frequent Positive Affect: Does Happiness Lead to Success? Psychological Bulletin, 131(6), 803-855.

Malik, A. (2013). Efficacy, hope, optimism and resilience at workplace - positive organizational behaviour. International Journal of Scentific and Research Publication, 3(10).

Margono, S. (2004). Metodologi Penelitian Pendidikan. PT. Rineka Cipta.

Mutawalli, L., Setiawan, S., \& Saimi, S. (2020). Terapi Relaksasi Otot Progresif Sebagai Alternatif Mengatasi Stress Dimasa Pandemi Covid-19 Di Kabupaten Lombok Tengah. JISIP (Jurnal Ilmu Sosial Dan Pendidikan), 4(3), 41-44. https://doi.org/10.36312/jisip.v4i3.1155

Muza, M. (2021). Pengaruh Beban Kerja Terhadap Kesejahteraan Psikologis Karyawan Di Masa Pandemi Covid-19 Dimoderasi Oleh Regulasi Emosi.

Nandini, D. (2016). Kontribusi Optimisme Terhadap Kebahagiaan Pada Karyawan. Jurnal Ilmiah Psikologi Gunadarma, 9(2), 97914.

Neuman, W. (2014). Social Research Methods: Qualitative and Quantitative Approaches Seventh Edition. Pearson Education Limited.

Ningsih. (2013). Subjective Well Being Ditinjau Dari Faktor Demografi (Status Pernikahan, Jenis Kelamin, Pendapatan). Jurnal Online Psikologi, 1(2).

Parker, S. L.; Jimmieson, N. L.; Amiot, C. E. (2013). Self-determination, control, and reactions to changes in workload: A work simulation. Journal of Occupational Health Psychology, 173.

Pflug, J. (2009). Folkk theories of happiness: a cross-cultural com-parison of conceptions of happiness in germany and south africa. Soc Indic Res, 551-563.

Pradiansyah, A. (1999). Menciptakan Komunikasi dan Sistem SDM yang Terpadu: Upaya Mewujudkan Hubungan Industrial yang Harmonis. Manajemen Usahawan Indonesia, 7-11.

Pryce-Jones. (2010). Happiness At Work: Maximazing Your Psychological Capital for Success. WilleyBlackwell.

Purmadani, A. S. (2014). Hubungan Antara Konsep Diri Dengan Optimisme Pada Remaja di Pengungsian Korban Erupsi Gunung Sinabung. Universitas Medan Area.

Ramdhan, M. R. (2020). Pengaruh Job Insecurity Dan Work Life Balance Terhadap Stres Kerja Pada Karyawan Outsourcing. http://eprints.umm.ac.id/61368/

Revesencio, J. (2015). Why Happy Employees are 12\% More Productive.

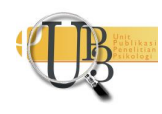


https://www.fastcompany.com/3048751/happy-employees-are-12-more-productive-atwork

Rocha, C; Crowell, J. H; Mccarter, A. K. (2006). The Effects of Prolonged Job Insecurity on the Psychological Well-Being of Workers. Journal of Sociology and Social Welfare, 9-28.

Rosenblattt, Z; Ruvio, A. (1996). A Test Multidimensional Model of Job Insecurity: The Case of Israeli Teachers. Journal of Organizational Behavior, 587-605.

Rotter, J. B. (1966). Generalized Expectancies for Internal Versus External Control of Reinforcement. Psychological Monographs: General and Applied, 1-28.

Saifudin, A. (2001). Metode Penelitian. Pustaka Belajar.

Saylor, M. C. (2004). Increased Stress Due to Job Insecurity. Ask The Internet Thera-Pist.Com.

Scheier, M. F., Carver, C. S., \& Bridges, M. W. (1994). Distinguishing Optimism From Neuroticism (and Trait Anxiety, Self-Mastery, and Self-Esteem): A Reevalution of The Life Orientatiton Test. Journal of Personaity and Social Psychology, 67(6), 1063-1078.

Seligman, M. E. P; Reivich, K; Jaycox, L; Gillham, J. (1995). The optimistic child: A proven program to safeguard children against depression and build lifelong resilience. Houghton Mifflin.

Seligman, M. E. P. (1991). Learning Optimism. Alfred A.Knopf.

Seligman, M. E. P. (2002). Authentic happiness: Using the new positive psychology to realize your potential for lasting fulfillment. Free Press.

Seligman, M. E. P. (2008). The Optimistic Child. PT. Mizan.

Skinner, E. A.; Edge, K.; Altman, J.; Sherwood, H. (2003). Searching for the structure of coping: A review and critique of category systems for classifying ways of coping. Psychological Bulletin, 216-269.

Stankevičiūtè, Ž., Staniškienė, E., \& Ramanauskaitė, J. (2021). The impact of job insecurity on employee happiness at work: A case of robotised production line operators in furniture industry in Lithuania. Sustainability (Switzerland), 13(3), 1-20. https://doi.org/10.3390/su13031563

Taylor, S. . (1991). Health Psychology. McGraw Hill.

Tiger. (1979). Optimism: The Biology of Hope, Simon \& Schuster. 18.

Trevino, L. K. (1986). Ethical Decision Making in Organizations: A Person-Situation Interactionist Model. Academy of Management Review, 601-617.

Troy, A. S.; Shallcross, A. J.; Mauss, I. B. (2013). A person-by-situation approach to emotion regulation: Cognitive reappraisal can either help or hurt, depending on the context. Psychological Science, 2505-2514. 
Veenhoven, R. (2003). Hedonism and Happiness. Journal of Happiness Studies, 4, 437-457.

Weiss, H. M; Cropanzano, R. (1996). Affective events theory: a theoretical discussion of the structure, causes and consequences of affective experiences at work. Research into Organizational Behavior, 1-74.

Weiss, H. M; Nicholas, J. P; Daus, C. S. (1999). An examination of the joint effects of affective experiences and job beliefs on job satisfaction and variations in affective experiences over time. Organizational Behavior and Human Decision Processes, 1-24.

Winurini, S. (2020). Permasalahan Kesehatan Mental.

Wursanto, I. (2009). Dasar-Dasar Ilmu Organisasi (2nd ed.). Andi.

Yang, Yuan; Li, Wen; Zhang, Qinge; Zhang, Ling; Cheung, T. X. Y. (2020). Correspondence Mental health services for older adults in China during the COVID-19. The Lancet Psychiatry.

Zajonc, R. B. (1998). Emotions. In The handbook of social psychology. McGraw-Hill.

Zheng, X., Diaz, I., Tang, N., \& Tang, K. (2014). Job insecurity and job satisfaction: The interactively moderating effects of optimism and person-supervisor deep-level similarity. Career Development International, 19(4), 426-446. https://doi.org/10.1108/CDI-10-2013-0121 